\title{
IbM ANTISIPASI GAGAL PANEN AKIBAT BANJIR MELALUI LUBANG RESAPAN BIOPORI (LRB) DI KABUPATEN MUSI RAWAS UTARA (MURATARA)
}

\author{
Mareta Widiya $^{1)}$,Yuni Krisnawati2) \\ ${ }^{1)}$ Jurusan PMIPA, Pendidikan Biologi, STKIP PGRI Lubuklinggau. \\ Email: maretawidiya@gmail.com \\ ${ }^{2)}$ Jurusan PMIPA, Pendidikan Biologi, STKIP PGRI Lubuklinggau. \\ Email: yunikris89@yahoo.co.id
}

\begin{abstract}
ABSTRAK
Permasalahan yang dihadapi Kabupaten Musi Rawas Utara Sumatera Selatan tepatnya di Kecamatan Karang Jaya dan Rupit adalah pernah dilanda genangan air. Lokasi kedua mitra ini terdapat genangan air saat intensitas hujan deras. Padahal mayoritas penghasilan yang ada di lokasi tersebut petani. Jika terdapat genangan air maka petani rentan sekali terkena gagal panen. Dalam rangka membantu menyelesaikan permasalahan mitra, melalui program IbM ini tim memberikan bantuan alat Lubang Resapan Biopori (LRB), memfasilitasi pembuatan pupuk yang dihasilkan dari pengendapan sampah organik dari LRB, mengadakan pelatihan dan penerapan lubang resapan biopori di lokasi mitra. Metode yang digunakan dengan penyuluhan, pelatihan, demonstrasi dan demoplot. Hasil yang diperoleh dari program ini berupa pengenalan dan pemberian bor Biopori di 2 Kecamatan mitra (desa Terusan dan desa Beringin Jaya). Hasil IbM ini diketahui setelah adanya teknologi LRB laju infiltrasi tanah menjadi lebih baik, perencanaan jumlah LRB yang efektif untuk lahan perkebunan jeruk yaitu 597 LRB dengan memperhatikan kondisi intensitas curah hujan dan kondisi tanah pada kedua daerah tersebut. Topografis lahan perkebunan jeruk yaitu dataran datar dengan jenis tanah lanau, sampah organik yang diendapkan terbentuk kompos dan hasil tanaman cabai warga meningkat. Luaran kegiatan ini adalah teknologi tepat guna berupa alat bor biopori, dan kemampuan mengolah sampah organik berupa sampah sayuran, daun-daun kering, dan sampah buah menjadi pupuk kompos.
\end{abstract}

Kata kunci: IbM, Banjir, LRB (Lubang Resapan Biopori)

\section{ABSTRACT}

The problem from Musi Rawas South Sumatera Utara precisely in Karang Jaya and Rupit was hit by a puddle. The location of both partners there are puddles when the intensity of heavy rainfall. Whereas the majority of existing income of farmers in these locations. If there are puddles of water that farmers vulnerable once exposed to crop failure. In order to help solve the problems of partners, through this IbM program team provides assistance tool Biopori Infiltration Hole (LRB), facilitating the manufacture of fertilizers produced from organic waste deposition of LRB, training and application of absorption holes biopores partner locations. The method used with counseling, training, demonstration and demoplot. The results obtained from this program in the form of recognition and awarding drill Biopori in 2 Subdistrict partners (village canal and village Beringin Jaya). The results of this IbM known after their infiltration LRB technology gets better, LRB number of effective planning for citrus plantation land, namely 597 LRB taking into consideration the intensity of rainfall and soil conditions in the two regions. Topographical citrus plantation is flat plains with silt soil type, organic waste is deposited to form compost and crop yields increased chili citizens. Outcomes of these activities is the appropriate technology in the form of a drill biopori, and ability to theprocess organic waste such as garbage vegetables, dried leaves, and fruit waste into compost.

Keywords: IbM, Flood, Infiltration hole, 


\section{PENDAHULUAN}

\section{Analisis Situasi}

Berdasarkan UU Nomor 16 Tahun 2013 Kabupaten Musi Rawas Utara merupakan daerah otonomi baru yang juga merupakan pemekaran dari kabupaten pemekaran dari wilayah kabupaten Musi Rawas. Cakupan kecamatan yang ada di Musi Rawas Utara yaitu, Karang Jaya, Rupit, Rawas Ulu, Nibung, Rawas Ilir, Karang Dapo, Ulu Rawas. Ibu Kota Kabupaten Musi Rawas Utara berkedudukan di Kelurahan Muara Rupit Kecamatan Rupit. Secara geografis, Kabupaten Musi Rawas Utara terletak antara

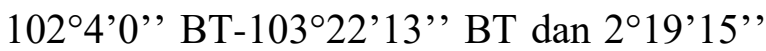
LS-36’30' LS. Letak Kabupaten Musi Rawas Utara yang merupakan salah satu kabupaten paling barat di provinsi Sumatera Selatan berbatasan dengan Provinsi Jambi di bagian utara, Kabupaten Musi Rawas di bagian selatan, Provinsi Bengkulu di bagian barat dan Kabupaten Musi Banyuasin di bagian timur (BPS Kabupaten Musi Rawas Utara 2015).

Secara administratif luas wilayah Kabupaten Musi Rawas Utara adalah seluas 6.008,55 $\mathrm{km}^{2} / 600.865,51 \quad \mathrm{Ha}$ (BPS Kabupaten Musi Rawas Utara 2015). Kepadatan penduduk yang tidak merata di Musi Rawas Utara membuat kegiatan ekonomi akan terpusat di beberapa lokasi seperti di Rupit dan Rawas Ulu. Kepadatan penduduk di Kecamatan Rupit termasuk desa Beringin Jaya yang tinggi harus mendapatkan perhatian karena bencana banjir pernah terjadi di daerah tersebut. Untuk daerah kecamatan karang jaya yakni desa Terusan rata-rata masyarakatnya memiliki mata pencaharian dengan berkebun, sebagai petani, peternakan dan perikanan juga sering mengalami banjir akibat dari pembuangan sampah sembarangan ke sungai, hingga dampaknya adalah timbulnya keresahan warga karna mengalami gagal panen.

Keadaan gagal panen tersebut menimbulkan tingkat kemiskinan di 2 Kecamatan tersebut, data yang didapat untuk kecamatan Karang Jaya adalah 2942 jiwa sedangkan Kecamatan Rupit sebesar 3008 jiwa (BPS Kabupaten Musi Rawas Utara 2015). Upaya pemerintah dalam mangatasi masalah tersebut akan dibantu oleh pihak peneliti dalam rangka membuat lubang resapan biopori. Lubang Resapan Biopori (LRB) merupakan salah satu teknologi/cara yang digunakan untuk meresapkan dan mengurangi limpahan air hujan dengan volume air yang lebih banyak ke dalam tanah, sehingga dapat meminimalkan terjadinya banjir dengan memanfaatkan sampah organik. Kehadiran LRB mampu mempercepat peresapan air hujan, mengatasi kekeringan, menambah cadangan air tanah, mengurangi emisi karbon dan metan serta mengubah sampah organik menjadi kompos (Brata, 2008). Penambahan bahan organik ke dalam LRB perlu dilakukan untuk peningkatan laju infiltrasi di dalam LRB (Juliandari et al. 
2013), sehingga pada saat musim penghujan, air yang mengalir diatas permukaan tanah akan mengikis hara tanah oleh karena butiran air hujan dan pada akhirnya terjadi run off yang berakibat pada semakin berkurangnya area infiltrasi air hujan. Usaha untuk meningkatkan kemampuan tanah dalam meresapkan air hujan adalah melalui teknologi pengendalian aliran permukaan dengan sistem biopori. Saluran dan lubang dalam sistem peresapan biopori digunakan sebagai simpanan dalam menampung dan meresapkan air tanah.

Melalui kegiatan IbM ini penelitipeneliti dari STKIP PGRI Lubuklinggau ingin menerapkan teknologi tepat guna yang sangat bermanfaat bagi masyarakat di 2 kecamatan tersebut. Transfer ilmu mengenai pemahaman tentang terbentuknya pupuk dari hasi lubang resapan Biopori juga sangat penting untuk disampaikan pada masyarakat sehingga nantinya dapat memperbaiki dan meningkatkan hasil panen masyarakat kabupaten Musi Rawas Utara khususnya desa Terusan dan Beringin Jaya.

\section{Permasalahan Mitra}

Permasalahan yang dihadapi oleh masyarakat tani di Kecamatan Karang jaya dan Rupit adalah rendahnya tingkat produktivitas hasil kebun/tani akibat dari gagal panen yang disebabkan oleh banjir. Banjir ini bisa disebabkan kurangnya kesadaran masyarakat untuk tidak membuang sampah di sungai. Mayoritas masyarakat tidak memperdulikan bagaimana keadaan tersebut akan berpengaruh terhadap tingginya kadar air di area/lahan pertanian atau perkebunan mereka. Banyaknya genangan air di tempat tumbuh tanaman menyebabkan terjadinya pembusukan pada tanaman, sehingga produktivitas hasil tani yang seharusnya optimal tapi justru jauh dibawah optimal. Selain itu, genangan air tersebut menyebabkan banyaknya jamur yang menjadi parasit bagi tanaman. Dengan demikian, petani-petani di wilayah tersebut perlu dibekali dengan ilmu dan teknologi tepat guna sehingga keberhasilan hasil kebun/pertanian di daerah tersebut dapat meningkat. Tidak hanya itu, di 2 kecamatan tersebut perlu dibekali pengetahuan sejak dini mengenai pentingnya untuk tidak membuang sampah sembarangan dan mampu membuat lubang resapan biopori, agar kelak masyarakat selalu bisa menjaga dan mencintai lingkungannya.

\section{TARGET DAN LUARAN}

\section{Target}

Kegiatan IbM ini memiliki beberapa target khusus, yaitu:

1) Demo lubang resapan Biopori di dua kecamatan (desa terusan dan desa beringin jaya) di kabupaten Musi Rawas Utara berhasil dilakukan.

2) Terselenggaranya kegiatan pelatihan, pembimbingan teknik pembuatan lubang resapan biopori pada masyarakat. 
3) Terlaksananya kegiatan membimbing dan mempraktekkan kepada warga di tempat dua kecamatan (desa terusan dan desa beringin jaya) di kabupaten Musi Rawas Utara untuk tidak membuang sampah di sungai dan bisa membuat teknik pembuatan lubang resapan Biopori.

\section{Luaran}

Luaran dari kegiatan program IbM Antisipasi gagal panen akibat banjir melalui Lubang Resapan Biopori (LRB) diKabupaten Musi Rawas Utara (MURATARA) ini yaitu berupa publikasi ilmiah di jurnal atau prosiding, publikasi pada media massa dalam bentuk draf, peningkatan omzet mitra, peningkatan kualitas produk, peningkatan pemahaman dan keterampilan masyarakat, peningkatan ketentraman atau kesehatan masyarakat, penerapan teknologi tepat guna biopori.

\section{METODE PELAKSANAAN}

\section{Prosedur dan Solusi yang ditawarkan}

Untuk mendukung tujuan tersebut Tim dari STKIP PGRI Lubuklinggau melakukan kegiatan IbM dengan dibagi menjadi dua tahapan, yaitu tahap persiapan, tahap pelatihan dan tahap pelaksanaan.

\section{Tahap persiapan}

Pada tahap persiapan dilakukan survei lokasi dan koordinasi dengan para kelompok tani dan kepala desa guna menentukan pelaksanaan kegiatan pembekalan dan pelatihan. Kegiatan pembekalan pada masyarakat dengan materi yang disampaikan meliputi :

1) Pembekalan tentang gagal panen yang dialami warga

2) Pembekalan lokasi lahan pertanian/perkebunan yang mudah banjir di desa Terusan dan desa Beringin jaya Kabupaten Musi Rawas Utara

3) Pembekalan teknologi pembuatan lubang resapan biopori

4) Pembekalan teknik pengomposan dari sampah organik seperti: daun-daun kering, sampah makanan dapur non kimia, ranting pohon dan lain-lain.

5) Pembekalan tentang analisis peningkatan hasil panen warga sebelum menggunakan lubang resapan biopori dan setelah.

Survei dan pengamatan topografi tanah serta data mengenai intensitas hujan dari Kabupaten Musirawas Utara juga dilakukan pada tahap persiapan.

\section{Tahap pelatihan dan pelaksanaan}

Pada tahap ini diadakan pelatihan dan pelaksanaan teknologi lubang resapan biopori. Sebelum IbM ini menggunakan metode survei lapangan dan eksperimen. Survei lapangan yaitu dengan melihat kondisi geografis dari dari area perkebunan warga. Eksperimen untuk mendapatkan data pengaruh dari lubang resapan biopori bagi produktivitas tanaman cabai setelah penerapan lubang resapan biopori. Dalam penerapan lubang resapan biopori diperlukan 
beberapa data yang penting untuk mendukung data $\mathrm{IbM}$ ini. Penentuan agar LRB lebih efektif dalam meresapkan air, jumlah LRB perlu dihitung pada setiap luas lahan dengan rumus berikut:

$$
\text { opori }=\frac{\text { Q Limpasan }}{\text { Laju Peresapan Air }\left(\frac{\text { Liter }}{\text { Jam }}\right)}
$$

Data yang mendukung dan perlu diketahui yaitu data intensitas curah hujan, debit limpasan curah hujan serta laju peresapan infiltrasi.

a. Intensitas curah hujan

$$
\frac{\mathrm{R} 24}{24} \mathrm{x} \quad[/ 3
$$

Ket:

I = Intensitas hujan ( $\mathrm{mm} / \mathrm{jam})$

$\mathrm{t} \quad=$ Durasi hujan (dalam jam)

R24 = Curah hujan maksimum dalam 24 jam (mm) dimodifikasi dalam kajian ini menjadi curah hujan harian (mm)

b. Debit limpasan air hujan

Rumus menghitung debit limpasan (run off) air hujan yaitu dengan rumus:

$\mathrm{Q}=0,278 \times \mathrm{C} \times \mathrm{I} \times \mathrm{A}$

Ket:

$\mathrm{Q}=$ Debit air larian $\mathrm{m}^{3} /$ hari hujan

$\mathrm{C}=$ Koefisien aliran

I = Intensitas hujan ( $\mathrm{m}^{3} /$ hari hujan)

$\mathrm{A}=$ Luas area larian (Victorianto, 2014)

c. Laju peresapan air yang terinfiltrasi

Setelah diterapkan lubang resapan biopori selanjutnya adalah analisis infiltrasi air di daerah penelitian. Analisis infiltrasi dengan menggunakan metode
Horton. Rumus metode Horton yaitu sebagai berikut (Juliastuti, 2011):

$$
\mathrm{F}=\mathrm{Fct}+\frac{1}{\mathrm{k}}(f o+f c)\left[1-e^{-k t}\right.
$$

Keterangan:

$\mathrm{F}=$ Tingkat infiltrasi ( $\mathrm{cm} /$ menit $)$

$\mathrm{Fc}=$ Tingkat infiltrasi setelah konstan (cm/menit)

Fo $=$ Tingkat infiltrasi awal (cm/menit)

$\mathrm{E}=2,71828$

$\mathrm{T}=$ Waktu konstan

$\mathrm{K}=1 / \mathrm{m} \log$

Laju infiltrasi diukur dengan cara berikut:

1. Meletakkan teko ukur dari plastik transparan yang telah berisi air

2. Memasukkan air kedalam teko ukur hingga kedalaman sesuai dengan volume yang diinginkan

3. Penutup lubang resapan lalu dibuka dan air dialirkan masuk ke lubang yang telah dibuat.

4. Ketika air masuk kedalam lubang hingga air yang telah disiapkan habis, kemudian diukur waktunya dengan menggunakan stopwatch, dan penurunan airnya diukur dengan mistar/penggaris.

Untuk menentukan laju resapan air, dihitung dengan menggunakan rumus:

Laju resapan air $=\frac{\text { ’liter }}{\text { am }}$

d. Penentuan jumlah lubang resapan biopori Secara spesifik jumlah lubang resapan 
biopori dapat ditentukan dengan mengetahui luasan tertentu dan intensitas hujan tertentu pula, dengan menggunakan persamaan (Brata, 2008)

$$
\mathrm{N}=
$$

Ket:

$\mathrm{N}=$ Jumlah lubang resapan biopori

$\mathrm{I}=$ Intensitas hujan terbesar $(\mathrm{mm} / \mathrm{jam})$

$\mathrm{L}=$ Luas bidang kedap air $\left(\mathrm{m}^{2}\right)$

$\mathrm{V}=$ Laju peresapan air rata per lubang (I/dt)

\section{HASIL YANG DICAPAI}

Kegiatan pengabdian masyarakat ini dilaksanakan dengan dibagi menjadi dua tahapan yaitu tahap persiapan, tahap pelatihan dan tahap pelaksanaan. Kegiatan pengabdian masyarakat ini di lahan perkebunan Bapak Omen Desa Terusan dan Bapak Hepi Desa Beringin Jaya.

Berikut hasil kegiatan pengabdian yang telah dilakukan oleh tim pengabdian antara lain:

\section{Tahap persiapan}

\section{Koordinasi survey untuk kegiatan pengabdian}

Kegiatan koordinasi dilakukan oleh tim pengabdian dengan dinas pertanian kabupaten Musirawas Utara, Camat Karang Jaya dan Rupit serta Kepala Desa di Desa Beringin Jaya dan Desa Terusan. Melalui observasi, lokasi yang disepakati yaitu di kebun jeruk Bapak Omen dan kebun cabai Bapak Heppi. Hasil wawancara diperoleh hasil bahwa dari pihak unsur setempat merespon dengan baik program kegiatan pengabdian ini.

\section{Tahap pelatihan dan pelaksanaan}

\section{Pelatihan Pembuatan Teknologi Lubang Biopori}

Salah satu tujuan dari kegiatan ini adalah diberikannya pemahaman atau pengetahuan tentang biopori yang sama sekali belum dikenal oleh warga di Desa Terusan dan Desa Beringin Jaya. Cara yang telah dilakukan yaitu dengan mengumpulkan data pemahaman masyarakat dengan teknik tes berupa tes tertulis. (tes tipe obyektif). Tes tertulis berisi 15 soal dengan pilihan jawaban benar dan salah. Tes bentuk benar-salah soalnya disajikan dalam bentuk pernyataan. Pernyataan tersebut mengandung nilai kebenaran Benar (B) atau salah (S), tetapi tidak keduanya sekaligus. Tes diberikan sebelum dan sesudah dilakukan pelatihan untuk mengetahui peningkatan pemahaman masyarakat tentang teknologi lubang resapan biopori.

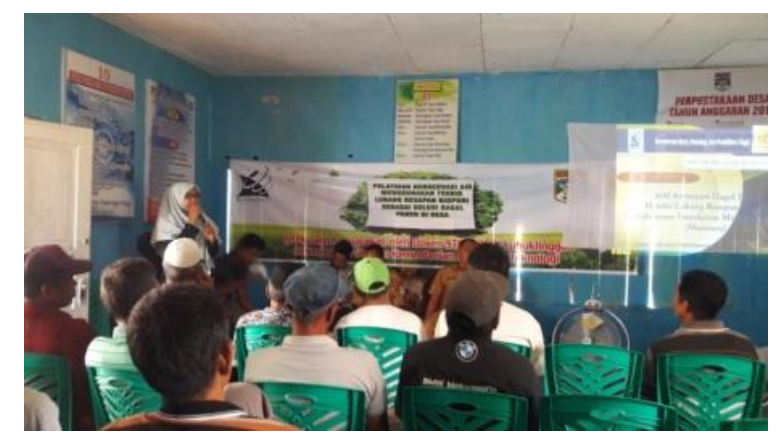

Gambar 1. Pelatihan Pembuatan Teknologi Lubang Resapan Biopori

Sebelum melaksanakan kegiatan praktik demoplot lubang resapan biopori, tim 
pengabdian masyarakat telah membekali masyarakat dengan materi yang disampaikan yaitu pembekalan tentang gagal panen yang pernah dialami warga yang menyebabkan ada beberapa tanaman seperti cabai, tanaman kacang kuning, jeruk dan lain-lain yang tergenang dan beberapa diantaranya membusuk. Sehingga menyebabkan gagal panen. Dimana salah satu penyebab adanya banjir tersebut yaitu kurangnya menjaga kesehatan lingkungan dan membuang sampah secara sembarangan. Berikut salah satu aktivitas warga yang dapat menyebabkan tingkat kesehatan rendah di desa Beringin Jaya. Serta foto setelah diberikan pembekalan materi tentang menjaga kesehatan lingkungan. (Gambar 2).
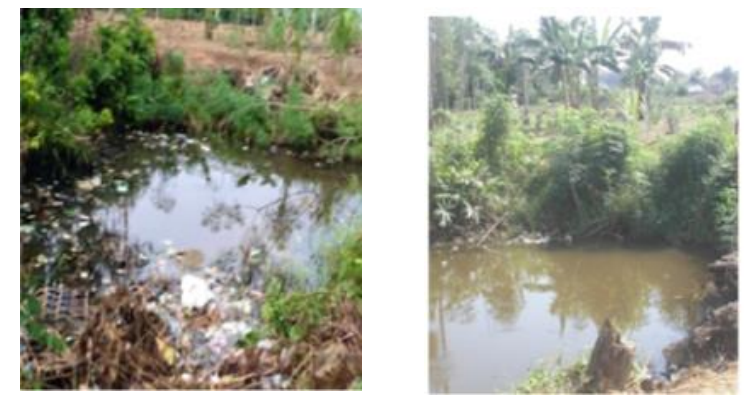

Gambar 2. Kiri (sebelum pembekalan materi) dan kanan (setelah pembekalan materi)

Selanjutnya, yaitu pembekalan materi tentang lokasi lahan perkebunan warga yang perlu diberikan teknologi LRB di Desa Terusan dan Desa Beringin Jaya di Kabupaten Musi rawas. Dari data yang disampaikan kemudian tim pengabdian masyarakat memaparkan bahwa perlunya diadakan teknologi lubang resapan biopori sebagai percontohan pada masyarakat di lokasi tersebut, agar keadaan banjir saat musim hujan dan kekeringan pada musim kemarau dapat menjadi solusi bagi masyarakat di kedua desa tersebut.

Pembekalan materi tentang teknik pengomposan dari berbagai sampah organik seperti: daun-daun kering yang, sampah makanan dapur non kimia, ranting pohon, buah-buah jeruk yang membusuk dan lain sebagainya. Selanjutnya yaitu pembekalan materi tentang bahwa hasil dari teknologi lubang resapan biopori tersebut diperoleh pupuk kompos yang sangat berguna bagi nutrisi tanaman (kesuburan tanah). Kemudian pembekalan dengan menerapkan pupuk kompos dapat meminimalisir pupuk kimia yang berbahaya bagi tanah. Dengan cita-cita bahwa pemberian pupuk kompos tersebut dapat berpengaruh dalam hal peningkatan hasil panen pada perkebunan milik warga.

Refleksi dari hasil pelatihan LRB yang telah dilakukan kepada masyarakat menggunakan analisis deskriptif dengan menggunakan skor N-gain. Normalized Gain (N-gain), yaitu selisih antara nilai postest dengan pretest dibagi dengan selisih antara skor ideal dengan skor pretest, dimana gain menunjukkan peningkatan pemahaman atau penguasaan konsep setelah diberi perlakuan.

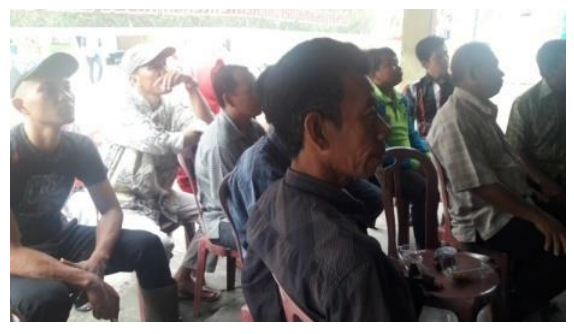

Gambar 3. Warga sedang serius mendengarkan pelatihan LRB 


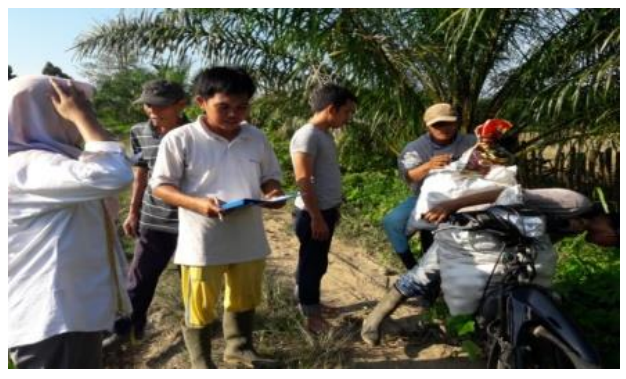

Gambar 4. Tes pemahaman setelah penerapan

Hasilnya menunjukkan bahwa pemahaman masyarakat mengalami peningkatan dari rendah menjadi tinggi, hal ini dapat ditunjukkan pada Gambar 5. sebagai berikut.

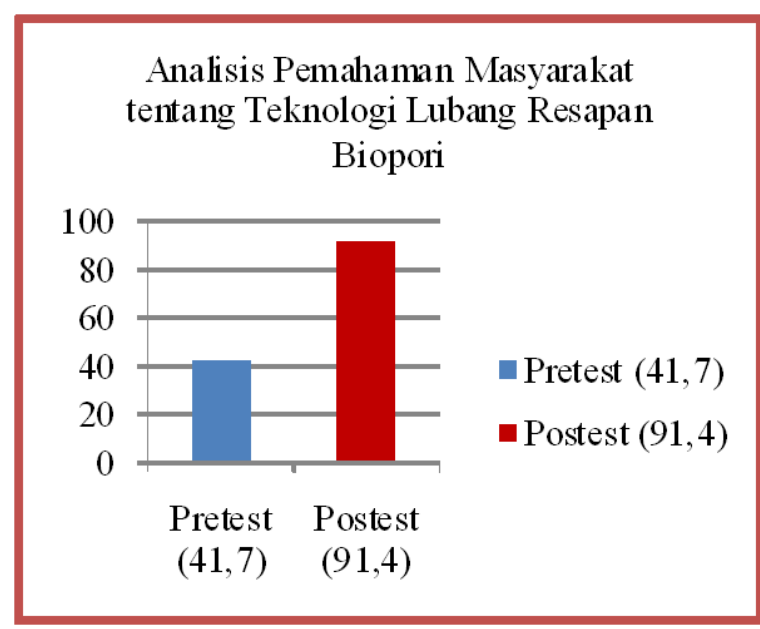

Gambar 5. Data hasil pemahaman masyarakat terhadap teknologi Lubang Resapan Biopori (LRB)

Berdasarkan Gambar 5. diketahui bahwa pemahaman masyarakat setelah diberikan pelatihan tentang teknologi lubang resapan biopori memiliki kategori tinggi karena nilai $(\langle\mathrm{g}\rangle)>0,7$ yaitu 0,85 . Hasil nilai rata-rata pretest, menunjukkan bahwa nilainya masih rendah dikarenakan rata-rata penduduk desa adalah bapak-bapak petani yang tidak melanjutkan pendidikannya. Tetapi, ketika diberikan ilmu baru, semangat dan antusias warga sangat tinggi. Hal inilah yang menyebabkan para warga tetap mengikuti pelatihan dan demontrasi cara pembuatan lubang resapan biopori dari awal sampai akhir. Melalui kegiatan demontrasi, masyarakat menjadi paham cara membuat lubang resapan biopori (LRB) yag benar. Masyarakat berpartisipasi aktif dalam mengikuti kegiatan ini meskipun jarak tempat pelatihan dengan kebun petani letaknya cukup jauh dari tempat rumah penduduk karena harus masuk ke dalam hutan.

\section{Pemberian Peralatan Teknologi Lubang Resapan Biopori}

Tim pengabdian masyarakat yang telah bekerja sama dengan Kementerian Riset dan Teknologi Pendidikan Tinggi (Kemenristekdikti) memberikan pipa dan alat bor biopori sebanyak 80 buah kepada mitra.

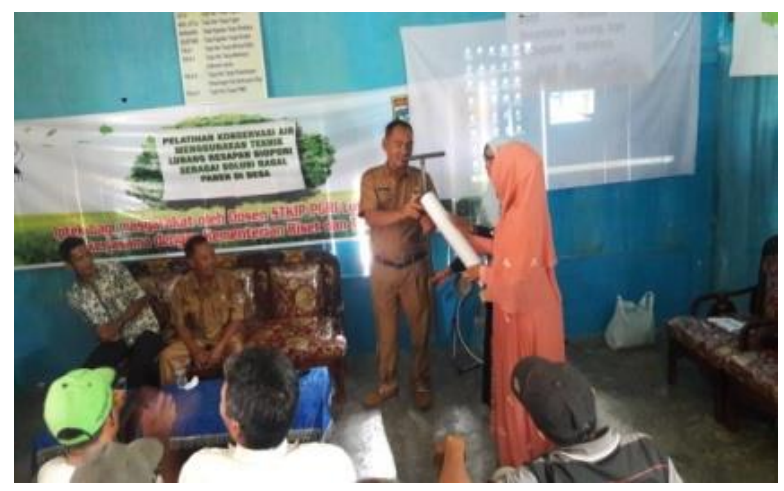

Gambar 6. Penyerahan alat bor biopori beserta pipa LRB secara simbolis

\section{Pelaksanaan Demoplot Teknologi Lubang Resapan Biopori}

Tim pengabdian masyarakat setelah melakukan pelatihan serta pembekalan materi tentang hal-hal yang terkait dengan gagal panen, banjir, lubang resapan biopori dan pembuatan pupuk kompos, kemudian tim pengabdian masyarakat mengajak masyarakat 
untuk melakukan penerapan demoplot teknologi lubang resapan biopori. Hasil yang yang telah dibuat yaitu yaitu 40 lubang di Desa Terusan (Kebun Jeruk Pak Omen) dan 40 Lubang di Desa Beringin Jaya (Kebun Cabai Pak Hepi). Lubang-lubang resapan biopori tersebut sudah difungsikan sejak awal bulan Agustus.

Lubang biopori tersebut dibuat berdiameter $15 \mathrm{~cm}$ dan kedalaman 40-100 $\mathrm{cm}$. Hal ini bertujuan agar fauna tanah dapat mendekomposisi sampah organik yang dimasukkan ke dalam lubang. Setelah lubang selesai dibuat, karena lokasi pembuatan berada di kebun petani jeruk, dan di lokasi tersebut banyak sekali sampah berupa daundaun tebu kering, buah-buah jeruk yang busuk dan telah jatuh dari pohonnya, serta sampah dapur yang sengaja dibawa oleh warga. Selanjutnya lubang ditutup dengan dengan penutup yang berlubang (dop pipa) untuk tempat masuknya air hujan. Tutup lubang yang digunakan terbuat dari paralon.

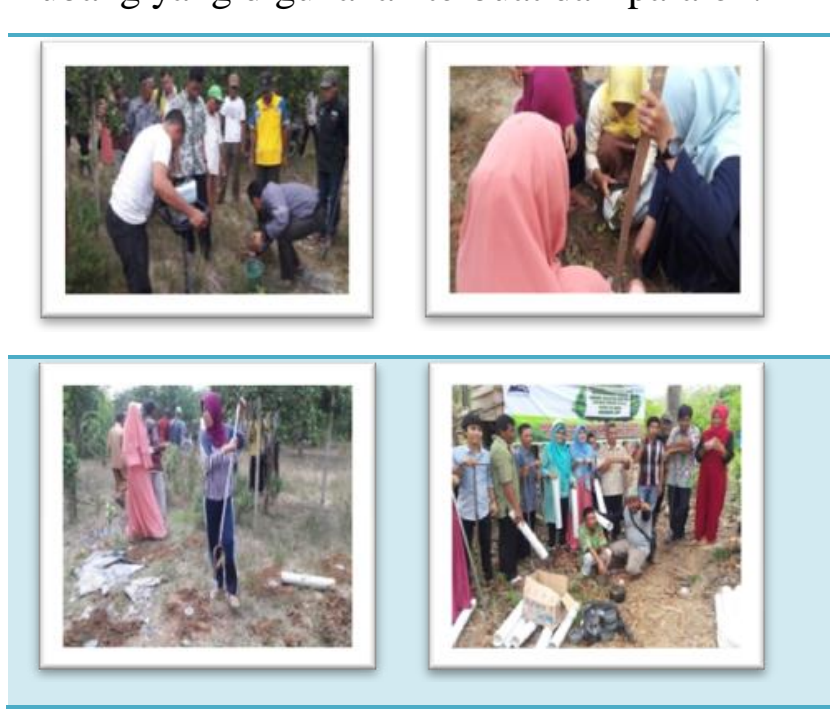

Gambar 7. Penerapan demoplot Lubang Resapan Biopori

\section{Produk Penerapan LRB}

Hasil penerapan IbM ini setelah kurang lebih 24 hari, lubang resapan biopori yang sebelumnya sudah diisi dengan sampah organik, banyak mengalami penyusutan dan ciri-ciri kompos mulai terbentuk (Gambar 8)

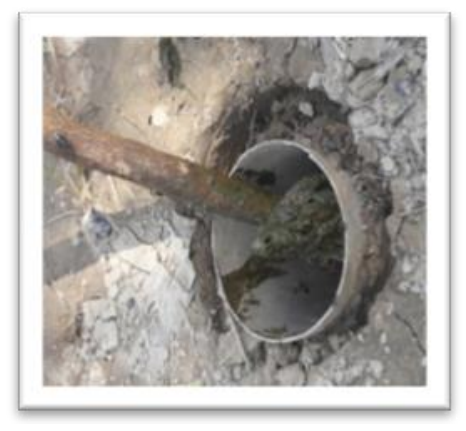

Gambar 8. Hasil timbunan sampah organik dalam Lubang Resapan Biopori

Hal ini menunjukkan bahwa lubang resapan biopori yang telah dibuat sangat efektif untuk menimbun sampah organik rumah tangga, serasah daun, dan sampah organik lainnya. Jika setiap petani mempunyai lubang resapan biopori, maka struktur dan kesuburan tanah dapat diperbaiki sehingga kualitas tanaman menjadi lebih baik. Karena selain mampu menyerap air dalam jumlah banyak, hasil sampingan dari lubang resapan biopori adalah pupuk kompos yang bisa digunakan langsung oleh petani.

Hasil dari lubang resapan biopori yang telah dilakukan yaitu diketahui bahwa laju infiltrasi tanah menjadi lebih baik, sehingga diharapkan saat adanya musim hujan tidak lokasi yang telah diterapkan IbM tidak mengalami genangan air dan saat musim 
kemarau tidak kekeringan. Sehingga kondisi tanah menjadi lebih subur. Berikut hasil produk lubang resapan biopori yang telah diperoleh Gambar 9. Pupuk dari LRB

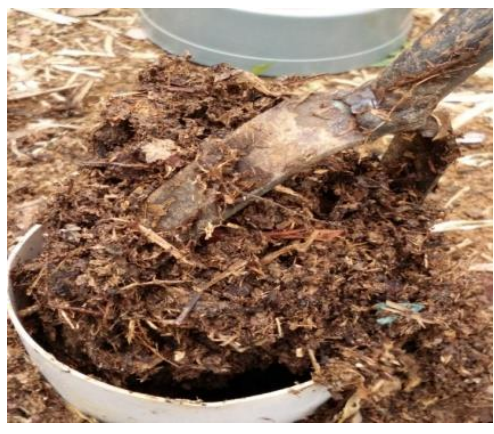

Gambar 9. Pupuk dari LRB

\section{Pengaruh LRB terhadap produktivitas tanaman cabai}

Perubahan yang bisa diamati pada hasil analisis peningkatan hasil panen warga yaitu tanaman cabai di Desa Beringin Jaya Kecamatan Rupit karena siklus pertumbuhan cabai yang relatif lebih cepat dibandingkan dengan tanaman jeruk. Dari data pengabdian diperoleh hasil bahwa pada tahun 2016 informasi dari Bapak Heppi bahwa hasil panen cabai yang diperoleh pada tahun 2016 adalah sebesar $220 \mathrm{Kg}$. Kemudian pada awal tahun 2017 yaitu $230 \mathrm{Kg}$ dan terakhir setelah penerapan teknologi Lubang resapan biopori serta pemberian pupuk kompos pada hasil panen tanaman cabai meningkat menjadi 310 Kg. Luas lahan kebun cabai tersebut yaitu 20 x $30 \mathrm{~m}$, dan dalam luas lahan lebih kurang 1 $\mathrm{m}^{2}$ bisa menghasilkan $0,5 \mathrm{Kg}$ cabai. Berikut Gambar 10. perbandingan hasil panen cabai yang diperoleh.

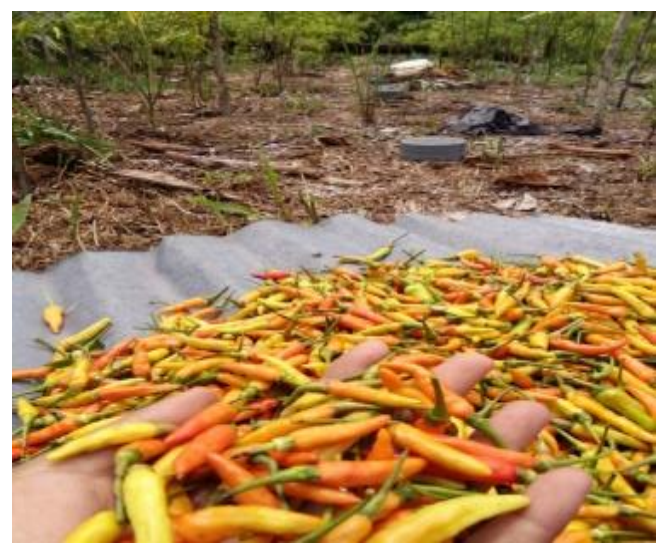

Gambar 10. Hasil panen cabai

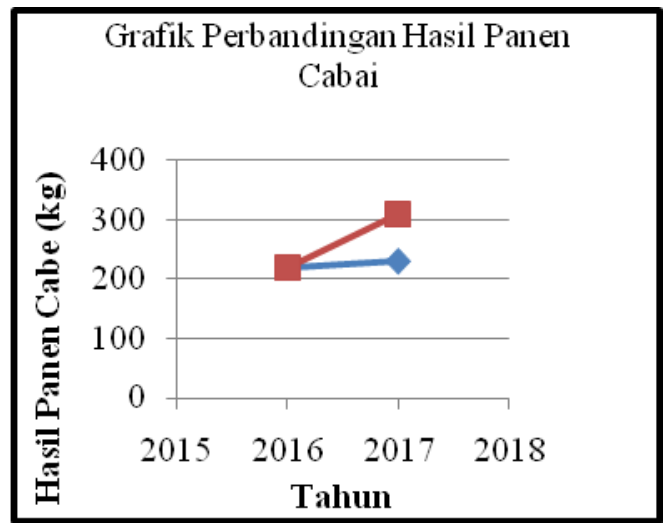

Gambar 11. Grafik Peningkatan produksi cabai

\section{Analisis peresapan air}

Penggunaan lubang resapan biopori merupakan salah satu teknologi yang efisien untuk diterapkan di lokasi lahan perkebunan cabai dan jeruk. Sehingga dapat mempertahankan debit air dan muka air tanah (cari sumber tentang lrb menahan air ). Diketahui bahwa intensitas hujan terbesar di Kabupaten Musirawas Utara yaitu 102 $\mathrm{mm} /$ hari dan luas bidang kedap air dari uji permeabilitas tanah di daerah perkebunan jeruk adalah $1 \mathrm{Ha}$ serta jenis tanah pada kawasan ini yaitu jenis tanahnya yaitu lanau dengan keadaan topografi adalah datar. Maka untuk nilai $\mathrm{k}$ diambil berdasarkan tabel dibawah ini: 
a. Intensitas curah hujan

Hasil analisis intensitas hujan di kawasan perkebunan jeruk yaitu dengan $\mathrm{R}=102$ $\mathrm{mm} / \mathrm{hari}=0,0042 \mathrm{~m} / \mathrm{jam}$. Dan nilai $\mathrm{t}$ dilihat dengan tabel kemiringan berikut:

Tabel. Kecepatan Aliran

\begin{tabular}{|l|l|}
\hline $\begin{array}{l}\text { Kemiringan Saluran } 1 \\
(\%)\end{array}$ & $\begin{array}{l}\text { Kecepatan rata-rata } \\
\text { V }(\mathrm{m} / \mathrm{dt})\end{array}$ \\
\hline$<1$ & 0.40 \\
\hline $1-<2$ & 0.60 \\
\hline $2-<4$ & 0.90 \\
\hline $3-<6$ & 1.20 \\
\hline $4-<10$ & 1.50 \\
\hline $5-<15$ & 2.40 \\
\hline
\end{tabular}

Hasil pengamatan dilokasi pengabdian diketahui bahwa kondisi topografinya yang relatif datar berada pada kemiringan $1<1 \%$ dan diketahui kecepatan rata-rata $\mathrm{v}(\mathrm{m} / \mathrm{dt})$ sebesar 0,4 . Sehingga nilai tc $=$ 20 detik.

$$
\begin{aligned}
& \frac{\mathrm{R} 24}{24} \mathrm{x} \quad\left[{ }^{1 / 3}\right. \\
& =\mathrm{x} \quad\left[{ }^{1 / 3}\right. \\
& =2,02 \mathrm{~mm} / \mathrm{hari}
\end{aligned}
$$

b. Luas bidang kedap air

Hasil analisis pengamatan jenis tanah di kawasan perkebunan jeruk yaitu tanah lanau. Maka nilai k mengikuti tabel 2 . berikut ini:

Tabel 2. Nilai K Jenis Tanah

\begin{tabular}{lll}
\hline \multirow{2}{*}{$\begin{array}{l}\text { Jenis } \\
\text { Tanah }\end{array}$} & $\mathrm{K}$ & \\
\cline { 2 - 3 } $\begin{array}{l}\text { Kerikil } \\
\text { bersih }\end{array}$ & $1,0-100$ & $(\mathrm{~cm} / \mathrm{det})$ \\
Pasir kasar & $1,0-0,01$ & \\
Pasir halus & $0,01-0,001$ & $2,0-0,02$ \\
Lanau & $0,001 \quad-02-0,002$ \\
& $0,00001 \quad 0,002$ \\
Lempung & $<0,000001$ & 0,00002 \\
\hline
\end{tabular}

Sumber: Braja M. Das
Berdasarkan tabel diatas dan sesuai dengan jenis tanah pada daerah perkebunan jeruk yaitu berupa jenis tanah alluvial, dan luas lahan perkebunan jeruk yaitu seluas 1 Ha. Sedangkan di perkebunan jeruk seluas 20 x $30 \mathrm{~m}$ jenis tanah berupa endapan rawa. Sehingga didapat luas bidang kedap air yaitu sebagai berikut:

$\mathrm{K} \times$ luas area $=0,001 \times 1 \mathrm{Ha}$

$$
=10.000 \mathrm{~m}^{2}
$$

Jadi luas bidang kedap air yaitu sebesar $10.000 \mathrm{~m}^{2}$

c. Laju peresapan air yang terinfiltrasi

Untuk mengukur laju peresapan air per lubang resapan biopori ditentukan berdasarkan infiltrasi tanah mengacu pada metode Horton. Model Horton menjelaskan bahwa dalam kapasitas infiltrasi tanah akan berkurang dengan bertambahnya waktu hingga mendekati nilai konstan. Laju infiltrasi dipengaruhi oleh pori-pori tanah. Semakin banyak jumlah pori-pori tanah maka kemampuan air untuk menyerap semakin tinggi sebaliknya semakin sedikit jumlah poripori tanah maka akan semakin rendah kemampuan tanah dalam menyerap air (Darwia, 2017). Model Horton dalam persamaan matematis sebagai berikut:

$\mathrm{F}=\mathrm{Fct}+\frac{1}{\mathrm{k}}(f o+f c)\left[1-e^{-k t}\right.$

Keterangan:

$\mathrm{F}$ = Laju infiltrasi nyata $(\mathrm{cm} /$ menit)

$\mathrm{Fc}=$ Laju infiltrasi tetap $(\mathrm{cm} / \mathrm{menit})$ 
Fo = Laju infiltrasi awal (cm/menit)

$\mathrm{E}=2,718281820$

$\mathrm{T}=\mathrm{Waktu}$

$\mathrm{K}=1 / \mathrm{m} \log$

Berdasarkan standar ukuran lubang resapan biopori yang memiki diameter $30 \mathrm{~cm}$ maka diasumsikan laju peresapan air rata-rata per lubang (liter/detik) dengan nilai k untuk tanah lanau adalah sebesar 0,0000939 liter/dtk $=33,804 \mathrm{~cm} / \mathrm{jam}$. Sehingga dapat dihitung jumlah lubang resapan biopori yang efektif di lahan perkebunan Jeruk milik Bapak Omen yaitu dengan menggunakan persamaan berikut:

$\mathrm{N}=$

$\mathrm{N}=\frac{: \mathrm{X} 10.000}{33.804}$

= 597 Lubang resapan biopori

\section{KESIMPULAN DAN SARAN}

\section{KESIMPULAN}

Hasil dalam penerapan Ipteks Bagi Masyarakat (IbM) yang dilakukan di Kabupaten Muratara khususnya di desa Terusan Kecamatan Karang Jaya dan desa Beringin Jaya Kecamatan Rupit ini dapat diambil kesimpulan sebagai berikut:

1. Warga sangat antusias mengikuti pelatihan dan demonstrasi demoplot Lubang Resapan Biopori (LRB) yang telah dilaksanakan oleh tim pengabdian. Semula pemahaman warga tentang teknologi LRB yaitu sebesar 41,7\%, setelah diberikan pelatihan dan percontohan pembuatan LRB menjadi $91,4 \%$.

2. Telah diberikan 40 alat bor biopori di Desa Terusan Kecamatan Karang Jaya dan 40 bor biopori di Desa Beringin Jaya Kecamatan Rupit.

3. Adanya perubahan kondisi lingkungan yang semula terdapat banyak sampah yang menumpuk baik di sungai maupun di kolam, setelah pelatihan LRB, pemberian poster untuk menjaga kebersihan dan penyampaian pentingnya untuk tidak membuang sampah sembarangan saat ini menjadi lebih bersih dari tumpukan sampah.

4. Pupuk kompos yang terbentuk dari LRB diberikan pada tanaman jeruk dan tanaman cabai mitra. Kompos tersebut dimanfaatkan untuk pertumbuhan Pada tanaman cabai sehingga terjadinya peningkatan panen dari tahun 2016 yang hanya $230 \mathrm{Kg}$ menjadi $310 \mathrm{Kg}$.

5. LRB yang efektif untuk di perkebunan warga adalah sebesar 597 Lubang resapan biopori.

\section{SARAN}

Adapun yang menjadi saran - saran dari hasil ipteks bagi masyarakat ini yaitu sebagai berikut:

1. Diharapkan warga menjadi lebih peduli lagi untuk tetap menjaga lingkungan yang sehat dan bersih dari sampah.

2. Agar program ipteks bagi masyarakat ini menjadi lebih berkelanjutan hasilnya 
maka sangat diperlukan pendampingan dari dinas lingkungan hidup dan pemerintah setempat untuk memperhatikan lokasi mitra secara berkelanjutan.

\section{UCAPAN TERIMA KASIH}

Penulis mengucapkan terima kasih kepada KEMENRISTEKDIKTI yang telah memberikan dana pengabdian ini. Serta STKIP PGRI Lubuklinggau yang telah membantu untuk melakukan pengabdian ini.

\section{DAFTAR PUSTAKA}

Brata, K. 2008. Lubang Resapan Biopori. Niaga Swadaya: Jakarta

BPS Kabupaten Musi Rawas Utara. 2015. Musi Rawas Utara dalam angka. BPS Kabupaten Musi Rawas Utara

Darwia, S. Ichwana \& Mustafril. 2017. Laju infiltrasi Lubang Resapan Biopori (LRB) Berdasarkan Jenis Bahan Organik Sebagai Upaya Konservasi air dan Tanah. Jurnal Ilmiah Mahasiswa Pertanian Unsyiah.

Gobel, Chintya. 2014. Perbandingan jenis sampah organik terhadap laju resapan air dengan menggunakan metode lubang resapan biopori (studi kasus di desa toluaya kecamatan bolaang uki kabupaten bolaang mongondow selatan).

Tesis Universitas Negeri Gorontalo (UNG): Gorontalo

Juliandari, M, Nirmala, A, Yuniarti, E. 2013. Efektivitas Lubang resapan biopori terhadap laju resapan (infiltrasi). Jurnal Untan, 1(1) hal: .Universitas Tanjungpura : Pontianak

Juliastuti, A \& Andrean, S. 2011. Studi Kapasitas Infiltrasi Metode Horton di Kampus Universitas Bina Nusantara Berdasarkan Debit Limpasan Permukaan. Vol 2 No 2 Desember. Bina Nusantara : Jakarta Barat

Victorianto, E. Qomariyah, S. \& Sobriyah, S.
2014. Pengaruh Lubang Resapan Biopori terhadap Limpasan Permukaan. Jurnal matriks teknik sipil. Fakultas teknik: Surakarta 